\title{
EXPLORING THE FACTORS IMPACTING THE SERVICE QUALITY OF THE AIRLINE INDUSTRY IN KSA-EXPATRIATES VIEWPOINTS
}

\author{
Abdul Razzak Hashmi \\ Assistant Professor, Department of Marketing, College of Business Administration, \\ AlBaha University, KSA- Kingdom of Saudi Arabia
}

\begin{abstract}
The whole purpose of this research is to find out whether there is any inconsistency in the expatriate's passenger service quality expectations and service quality acuities in the airline and also to find out if there is any significant change in service quality anticipation and perception of the expatriate's passengers coming from diversified demographic characteristics. A 5-dimensional scale considered the landmark in service quality had been used to access the above objectives. A face to face interview was conducted at Jeddah domestic airport, KSA. A total of 319 respondent's passengers were interviewed. The data was analyzed by SPSS 23.AMOS software was also used to examine the data using Structural Equations Modelling (SEM) analysis. Reliability and empathy were the two significant factors that positively impacted the airline industry's consideration of service quality. The rest three factors had little or no significance in service quality in airlines concerning expatriate's passengers.
\end{abstract}

Key words: Expatriate's, Service Quality, SERVQUAL, Structural Equations Modelling (SEM)

Cite this Article: Abdul Razzak Hashmi, Exploring the Factors Impacting the Service Quality of the Airline Industry in KSA-Expatriates Viewpoints, International Journal of Management, 11(12), 2020, pp 1570-1579.

http://iaeme.com/Home/issue/IJM?Volume $=11 \&$ Issue $=12$

\section{INTRODUCTION}

The airline industry nowadays has been considered as the backbone of long-distance travel. Managing any sector in Saudi Arabia has become very competitive, and any business needs to deal with 2030 regulations (Hashmi \& Zia, 2020)(Hashmi, 2018).

Customer service and its quality is a significant accomplishment from the scenarios of business administration. Most previous service understandings form a level at which the 
customers anticipate the service (Zia \& Hashmi, 2019).Lately, businesses have been contending with each other with their high-tech investments and their equipment. Particularly, in a service sector like airline services, it is so significant to have efficient paraphernalia and great technology(Aydin, 2012).

Saudi Arabia is evolving into an intelligent region in the Middle East with many techsavvy users(Zia, 2020) who are well aware of the technology and its uses. The service sector has developed at an extraordinary proportion. The last 15 years have seen a dramatic increase of curiosity in services, as academics and practitioners alike have comprehended the philosophical structural shift toward services in every advanced economy(Sheffield University 1998, 1998).

Globalization and the appearance of information technology have transformed the customers' socioeconomic values, and human relations are now expressively being substituted by human-technology collaborations (Choudhuri, 2014). The air transportation industry is evolving speedily in today's world. Similarly, with this advancement, the number of airline companies and travelers is growing significantly. Thus, examining and understanding customers' anticipations in airline services are getting prominence among airline companies(Gures et al., 2011).

\section{LITERATURE REVIEW}

\subsection{Service Quality}

The 22 service quality items in the original SERVQUAL scale were reformed to fit the airline's requirements. This was in line with the guidelines(Parasuraman et al., 1994).Incessant enhancement of customer (user) service is indispensable to the positive expansion of business in today's exceedingly competitive environment(Jayasundara, 2011).

The progression of inventions chiefly, the methodological advances of the knowledge era have made a momentous contribution to the market economy in altering the expression of its amenities. Today's market economy's service module is related to significance to merchandises(Jayasundara, 2011).

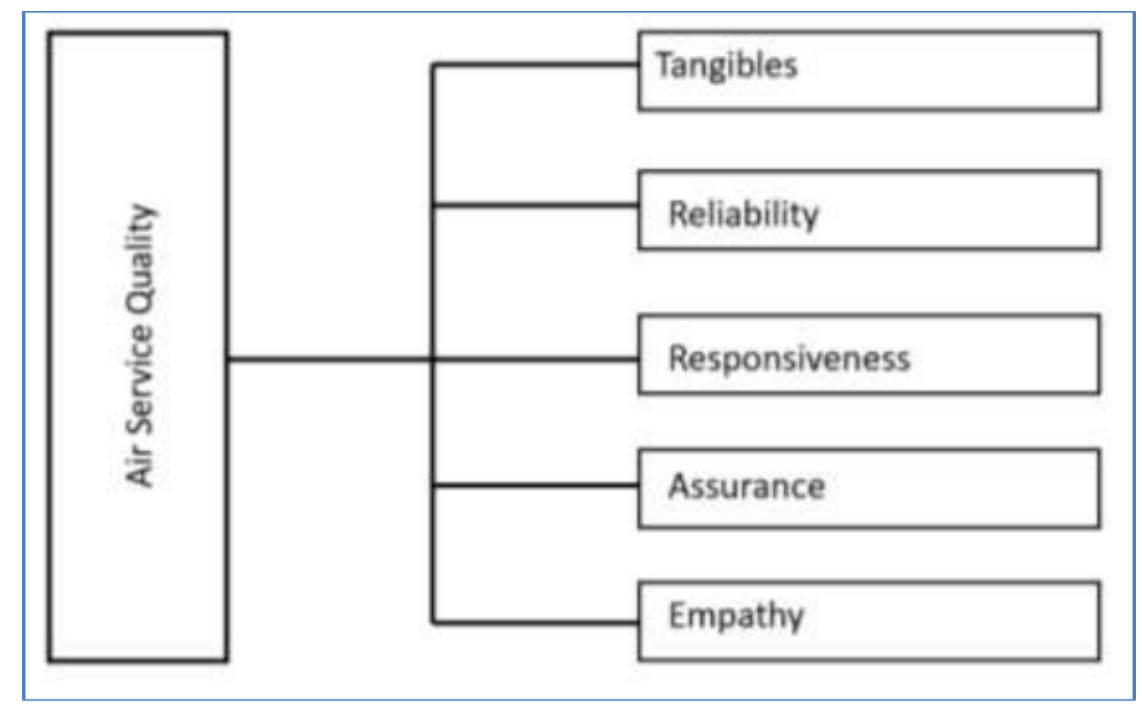

Figure 1 Airline Service Quality Scale (ASQS) Mode

*Source: Airline Service Quality Scale (ASQS) proposed by Kenan Aydina and Seda Yildirimb(Aydin \& Yildirim, 2012). 
The accurate and perfect assessment of service quality requires employing a consistent notion with inclusive standards and actual measurement methods as a valuable framework (Haghighat, 2017). However, diverse studies have generated diverse results in relations to the significance of the five dimensions to consumers (Abukhalifeh, 2015).Modern business realm is very much competitive and the accomplishment in the rivalry is attained primarily through giving satisfaction to the eventual customer. In service oriented industry, it is very tough to set a customary statute to satisfy customers (Islam, 2013).

\subsection{Service Quality in Airlines}

Recent years have seen increasing academic concentration in the notion of airspace(Lin, 2015). What travelers anticipate has become critical for airline companies to deliver the anticipated service quality and travelers gratification(Gures et al., 2011). Throughout the last two eras, the topic of service quality has been extensively documented due to its vital contribution to customer satisfaction enhancement(Shirouyehzad et al., 2012).Assessment of passengers' insights and prospects concerning service quality using non-fuzzy approaches disregards the vagueness convoluted in specific conclusions(Torres, 2014).Appraisal of airlines constructed on service quality standards can help expand airlines' progressions and give direction to travel agencies to deliver improved choices for travelers and vacationers(Keshavarz Ghorabaee et al., 2017).

We advanced a distinguished Bertrand high-speed rail and airline system which scrutinizes the effects of international air conveyance liberalization(Adler et al., 2014); this liberalization and the forthcoming development of the airline industry is wholly constructed on the service quality. Traveler gratification is an initial apprehension to airlines. It is an essential competitive advantage that airlines require (Wafik et al., 2017) for further enhancement in the service sector. Air travel has altered human beings' lives and how they demeanor their business (Wafik et al., 2017).

The speed expansion, dispersion, and growing utilization of technologies have altered how airlines interact with their passengers (Budd \& Vorley, 2013).In the past decades, both the number and quality of airports worldwide have been developing considerably. Regardless of this fact, research areas such as performance appraisal and ranking of these airports are based on different sets of standards and practices (Shojaei et al., 2018). in order to improve passenger gratification, both service quality and perceived value must be given solemn contemplation. However, passenger satisfaction depends upon enhancement in the quality of service delivered by the transportation system, which in turn impacts passengers' opinion of value (Irtema et al., 2018). Loyalty is a significant subject for the sustainability of the business. Connation's with the passengers should be erected well in order to attain their gratification and subsequently loyalty. Additionally, the airline segment has its explicit situations to be reflected in order to earn customer satisfaction.

\section{OBJECTIVES OF THE STUDY}

To explore the factors responsible for airline service quality in airlines of KSA.

To investigate the impact of factors responsible for airline service quality in KSA.

\subsection{The Hypothesis of the Study}

Null hypothesis: there is no probability to have a linear relationship between the airline's service quality (dependent) and independent dimensions (Tangibles, Reliability, Responsiveness, Assurance, and Empathy.)

Statements of hypothesis 
H1: there is a significant impact of Tangibles (T) on Service Quality (SQ).

H2: there is a significant impact of Reliability (R) on Service Quality (SQ)

H3: there is a significant impact of Responsiveness (RE) on Service Quality (SQ)

H4: there is a significant impact of Assurance (A) on Service Quality (SQ)

H5: there is a significant impact of Empathy (E) on Service Quality (SQ)

\section{RESEARCH METHODOLOGY}

The primary data was composed through a questionnaire designed on the five dimension scale as suggested by (Parasuraman et al., 1994); the questionnaire was used to interview the passengers face to face at Jeddah domestic airport. Three hundred nineteen (319)respondent's passengers responded. The random sampling data collection method was used, and the designated airport was Jeddah. Even though there was no need for the validity test as it has already been worked upon (Sosianika \& Najib, 2018), the Reliability test was conducted. Many studies have used this scale to explore the service quality. A 5 point Likert scale $\{1-$ Strongly Disagree to 5-Strongly Agree was chosen for data collection (Suhartanto \& Noor, 2012)within all 22 questions, and the respondents have to respond to only one option. The most beneficial SERVQUAL's service quality dimensions, which includes 22-items, were used. These essential items were tangibles, reliability, assurance, empathy (Aydin \& Yildirim, 2012). It includes only the expatriate's passenger's responses. The data was analyzed in SPSS 23.

\subsection{Demographics}

A total of 319 respondent airline passengers were interviewed face-to-face; 160 were male, and 159 were female passengers. 111 passengers were (i.e., 34.8\%) were between the age group of 35-44 followed by age group 18-24 (i.e., 30.4\%) the least were between the 45-54 age group, one of the dominant reason for this is the majority of the airline passenger to and fro in Saudi are for employment purpose (154, i.e., $48.3 \%$ ), and $28.5 \%$ and $20.1 \%$ were traveling for business and umrah (visiting the holy site of Muslims) purpose.

Of the total $57.4 \%$ (i.e., 183 ) of the respondents, passengers were married, and a majority of 36.4 (i.e., 116) of the airline respondents passengers were having high education, and $21.9 \%$ had only essential elementary school qualification; again, this can be the reason of the required labor force by KSA. $27.0 \%$ of respondent's passengers had an income within the range of 3001-5000. As for a KSA visit, employment stood first at 48.3\%, and business and umrah followed at $28.5 \%$ and $20.1 \%$, respectively. The number of flights in each year (i.e., traveling visits to KSA in a year), $69.3 \%$ (i.e., 221) respondents passengers travel only once whereas $14.1 \%$ indicated they travel to and from KSA, 3 times per year. When the question was posed to the respondent's expatriate's passengers about the factors of choosing the airline, the top position of preference was taken by the price that stood at 180 passengers.

\section{ANALYSIS AND FINDING}

Table 1 Reliability Statistics

\begin{tabular}{|c|c|c|}
\hline & $\begin{array}{c}\text { Cronbach's Alpha } \\
\text { Based on } \\
\text { Cronbach's Alpha }\end{array}$ & N of Items \\
\hline .849 & .850 & 22 \\
\hline
\end{tabular}


The reliability of the airline's service quality scale (ASQS) was checked by calculating the value of Cronbach's Alpha. In the beginning, only the overall Cronbach's alpha value was calculated, and later on, the individuals were calculated. Table 1, Table 2 depicts the reliability statistics of both the overall and the individual Cronbach's Alpha Value.

Table 1 calculated the reliability by Cronbach's alpha based on standardized items, and the value stood at 0.849 , which indicates a high reliability of the scale. Similarly, the reliability statistics of selected factors were checked in table 2. The factor's reliability and empathy stood clear ahead in their alpha value, which stood at 0.708 and 0.714 . Simultaneously, the remaining three factors stood at 0.661 tangibles, 0.686 responsiveness, and lastly, 0.669 assurance. By reliability, we mean the dependability and firmness of the scale.

Table 2 Reliability Statistics of Selected Factors

\begin{tabular}{|c|c|l|c|c|}
\hline $\begin{array}{c}\text { Sr. } \\
\text { No }\end{array}$ & Dimensions & Chronbach Alpha & Value & $\begin{array}{c}\text { No. of } \\
\text { items }\end{array}$ \\
\hline 1 & D1 & Tangibles & .661 & 3 \\
\hline 2 & D2 & Reliability & .708 & 4 \\
\hline 3 & D3 & Responsiveness & .686 & 3 \\
\hline 4 & D4 & Assurance & .669 & 3 \\
\hline 5 & D5 & Empathy & .714 & 4 \\
\hline
\end{tabular}

*Source: SPSS Output

Table 3 Model Summary

\begin{tabular}{|c|c|c|c|c|}
\hline Model & R & R Square & $\begin{array}{c}\text { Adjusted R } \\
\text { Square }\end{array}$ & $\begin{array}{c}\text { Std. Error of the } \\
\text { Estimate }\end{array}$ \\
\hline 1 & $.695^{\mathrm{a}}$ & .483 & .475 & 2.10721 \\
\hline
\end{tabular}

*Source: SPSS Output

a. Predictors: (Constant), Empathy, Responsiveness, Reliability, Assurance,

Tangibles

Table 3 depicts the summary results of multiple linear regression analysis and overall fit statistics. It was found that the adjusted $\mathrm{R}$ stood at .695 with the $\mathrm{R}^{2}=.483$. This means that the linear regression explains $48.3 \%$ of the amount of variance in the DV (i.e., Airline Service Quality) that is accounted for or explained by the IV(s), i.e., tangibles, reliability, responsiveness, assurance, and empathy.

Table $4 \mathrm{KMO}$ and Bartlett's Test

\begin{tabular}{|ll|l|}
\hline Kaiser-Meyer-Olkin Measure of Sampling Adequacy. & 848 \\
Bartlett's Test of Sphericity & Approx. Chi-Square & 2076.088 \\
& df & 231 \\
& Sig. & .000 \\
\hline
\end{tabular}

*Source: SPSS Output

Table 4 shows the KMO and Bartlett's test values. The Kaiser-Meyer-Olkin Measure of Sampling Adequacy is used for factor analysis, and the indicated value is .848 , which is Bartlett's Test of Sphericity $=2076.088$ and its significance $=0.000$. Therefore, the 22 subfactors were reduced to five main factors with eigenvalues greater than 1 . 
Table 5 ANOVA $^{\mathrm{a}}$

\begin{tabular}{|ll|c|c|c|c|c|}
\hline \multicolumn{1}{|c|}{ Model } & $\begin{array}{c}\text { Sum of } \\
\text { Squares }\end{array}$ & df & Mean Square & F & Sig. \\
\hline 1 & Regression & 1297.646 & 5 & 259.529 & 58.448 & $.000^{\mathrm{b}}$ \\
Residual & 1389.822 & 313 & 4.440 & & \\
Total & 2687.468 & 318 & & & \\
\hline
\end{tabular}

a. Dependent Variable: Service Quality

b. Predictors: (Constant), Empathy, Responsiveness, Reliability, Assurance, Tangibles

The above table is the F-test. The linear regression F-test has the null hypothesis that the model explains zero variance in the dependent variable (in other words $\mathrm{R}^{2}=0$ ). The F-test is highly significant which is 0.00 , thus we can assume that the model explains a significant amount of the variance independent variable(service quality).

Table 5 Depicts the

Table 6 Coefficients ${ }^{\mathrm{a}}$

\begin{tabular}{|ll|c|c|c|c|c|}
\hline \multirow{2}{*}{ Model } & \multicolumn{2}{|c|}{$\begin{array}{c}\text { Unstandardized } \\
\text { Coefficients }\end{array}$} & $\begin{array}{c}\text { Standardized } \\
\text { Coefficients }\end{array}$ & & \\
\cline { 2 - 4 } & B & Std. Error & Beta & t & Sig. \\
\hline $1 \quad$ (Constant) & 3.106 & .789 & & 3.939 & .000 \\
& Tangibles & .175 & .072 & .124 & 2.441 & .015 \\
& Reliability & .444 & .054 & .380 & 8.154 & .000 \\
Responsiveness & .226 & .071 & .156 & 3.188 & .002 \\
Assurance & .165 & .072 & .115 & 2.289 & .023 \\
Empathy & .207 & .050 & .197 & 4.157 & .000 \\
\hline
\end{tabular}

a. Dependent Variable: Service_Quality

Table 6 shows the multiple linear regression estimates, including the intercept and the significance levels. In multiple linear regression analysis, it was initiated that the model has a high level of significance intercept. Out of the five factors, two of them had a high level of significance, i.e., namely reliability and empathy (.000). Whereas tangibles, responsiveness, and assurance were not significant (i.e., .015, .002, and .023). Further, it can be interpreted that for every 1 -unit increase in airline service quality, $48.3 \%$ can be explained in this model. $\mathrm{SQ}=$ Service Quality, $\mathrm{T}=$ Tangibles, $\mathrm{R}=$ Reliability, $\mathrm{RE}=$ Responsiveness, $\mathrm{A}=$ Assurance, $\mathrm{E}=$ Empathy

\section{Dependent Variable: Service Quality(Y)}

Predictors: Tangibles ( $\left.\mathrm{X}_{1}\right)$, Reliability (X2), Responsiveness ( $\left.\mathrm{X}_{3}\right)$,Assurance (X4), Empathy (X).

\section{Model Produced}

$\mathrm{Y}=$ Service Quality $(\mathrm{Y})=$ Constant $+($ Tangibles $)+($ Reliability $)+($ Responsiveness $)+$ (Assurance) + (Empathy) $\mathrm{Y}=0.175+0.444+0.226+0.165+0.207$

It was also found that unit increase in reliability and empathy will have a positive impact, and tangibles, responsiveness, and assurance have a negative impact on the service quality. 


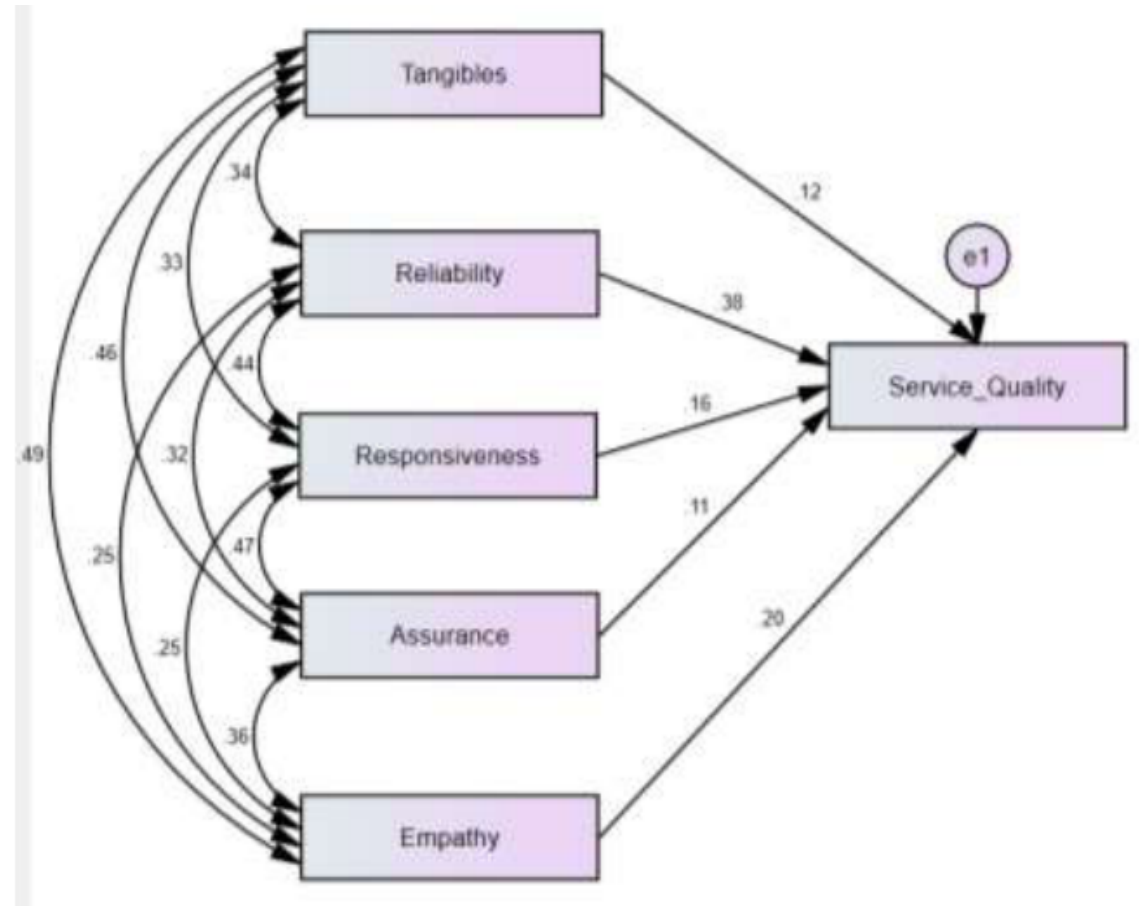

Figure 1 SEM output of Standardised Estimates

*Source: SPSS Amos.

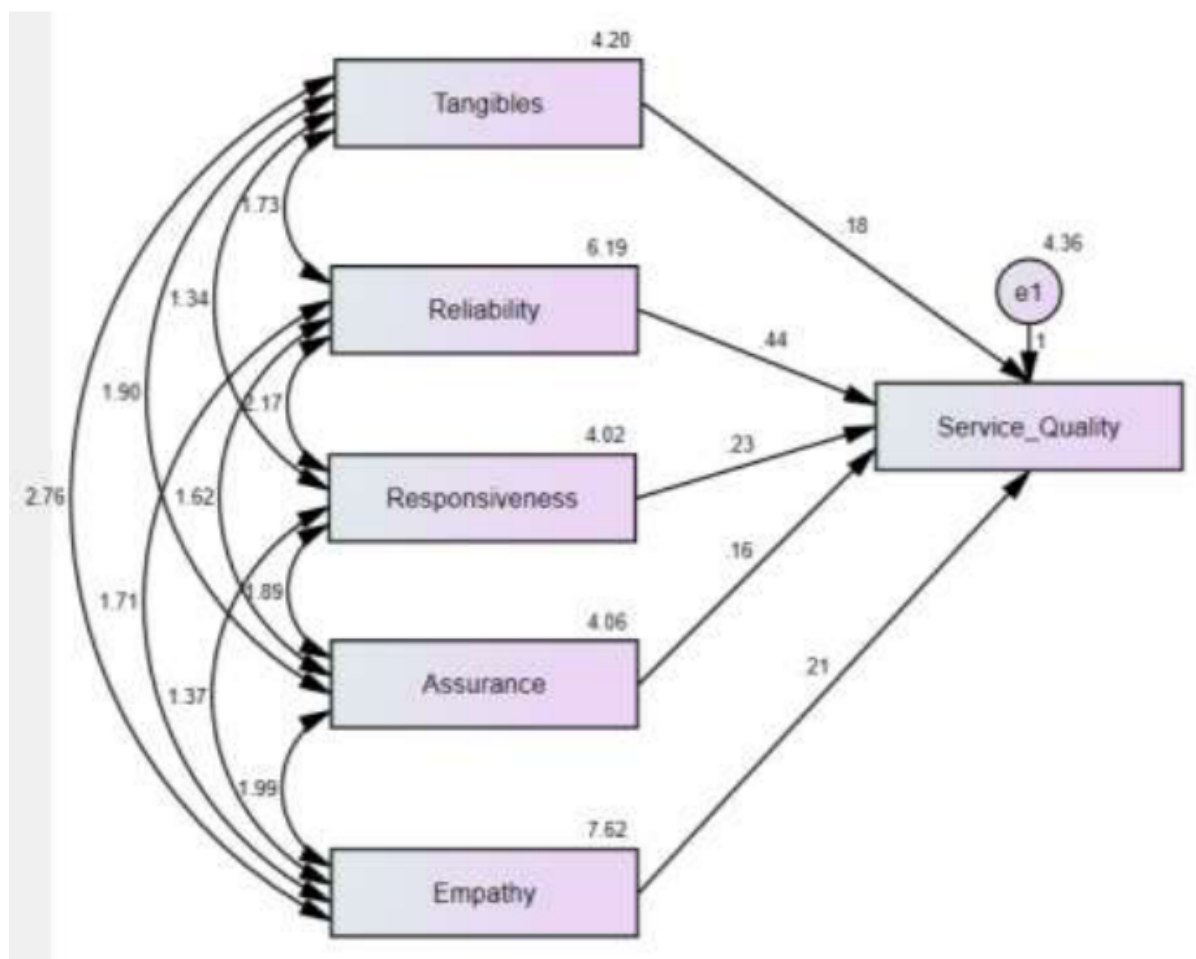

Figure 2 SEM output of Unstandardized Estimates

*Source: SPSS Amos.

Figure 1 depicts that two factors, reliability, and empathy, have a significant impact on service quality: .38 and .20 , compared to other factors tangibles, responsiveness assurance (i.e. .18,.23,.16.) 


\section{CONCLUSION}

The Saudi owns airline started functioning in 1945 and it had improved its quality in term to every sense. At present there is stiff competition in KSA, having numerous domestic and international airlines operating in and out of KSA. In this study the findings are based on data collected only from expatriate's respondents. The study included 5 dimensions Tangibles, Reliability, Responsiveness, Assurance and Empathy. The travellers were asked to give their three preferences for travelling on the airlines and their first choice was price was the first preference. Reliability was obtained by using Cronbach's Alpha and the scale was found to be reliable. The most significant dimension in SERVQUAL scale was found to be reliability and empathy.

\section{RECOMMENDATIONS}

Pondering upon the study it can be recommended to the airline industry that for flourishing and to maintain a competitive edge over their competitors it is necessary to cut the travelling cost ticket, even at the cost of ambiance. As the majority of travellers are the expatriates in and out of KSA. It will be worth a try

\section{FUTURE RESEARCH DIRECTION}

The demographics of the sample can be used for the future research with bigger sized sample. Further In this study it was observed that tangibles, responsiveness assurance scored a negative correlation. This negative beta value of tangibles, responsiveness assurance shows its inverse relationship with service quality which is an area of research to explore. These findings need further investigation of motives beyond the scope of this research which can justify inverse relationship of service quality and the three dimensions (tangibles, responsiveness assurance).

\section{REFERENCE S}

[1] Abukhalifeh, A. N. (2015). Customer Perceptions of Service Quality in Luxury Hotels in Petra and Aqaba, Jordan: An Exploratory Study. International Journal of Tourism \& Hospitality Reviews, 1(1), 37. https://doi.org/10.18510/ijthr.2014.116

[2] Adler, N., Fu, X., Oum, T. H., \& Yu, C. (2014). Air transport liberalization and airport slot allocation: The case of the Northeast Asian transport market. Transportation Research Part A: Policy and Practice, 62, 3-19. https://doi.org/10.1016/j.tra.2014.02.003

[3] Aydin, K. (2012). Service Quality in Airline Businesses: A Research on THY. Kocaeli Üniversitesi Sosyal Bilimler Enstitüsü Dergisi, 24, 35-49.

[4] Aydin, K., \& Yildirim, S. (2012). The measurement of service quality with SERVQUAL for different domestic airline firms in Turkey. Serbian Journal of Management, 7(2), 219-230. https://doi.org/10.5937/sjm7-1317

[5] Budd, L., \& Vorley, T. (2013). Airlines, apps, and business travel: A critical examination. Research in Transportation Business and Management, 9, 41-49. https://doi.org/10.1016/j.rtbm.2013.08.004

[6] Choudhuri, P. S. (2014). (C) i a e m e. International Journal of Management (IJM), 6502, 117130 .

[7] Gures, N., Arslan, S., \& Yilmaz, H. (2011). A Comparison of Airline Service Expectations Between. Journal, International Social, Of Studies, Humanity, 3(2), 377-386. 
[8] Haghighat, N. (2017). Airline service quality evaluation: A review on concepts and models. Economics, Management and Sustainability, 2(2), 31-47. https://doi.org/10.14254/jems.2017.2-2.4

[9] Hashmi, A. R. (2018). Faith Marketing A Theoretical Article. Sinergi : Jurnal Ilmiah Ilmu Manajemen, 8(2). https://doi.org/10.25139/sng.v8i2.1023

[10] Hashmi, A. R., \& Zia, A. (2020). Customer Relationship Towards Boundary Spanner In-Store ( Bakhala ): A Saudi Perspective. Academy of Marketing Studies Journal, 24(2), 1-8. https://www.abacademies.org/journals/academy-of-marketing-studies-journal-inpress.html

[11] Irtema, H. I. M., Ismail, A., Borhan, M. N., Das, A. M., \& Alshetwi, A. B. Z. (2018). Case study of the behavioural intentions of public transportation passengers in Kuala Lumpur. Case Studies on Transport Policy, 6(4), 462-474. https://doi.org/10.1016/j.cstp.2018.05.007

[12] Islam, M. A. (2013). Customer Satisfaction and Customer Loyalty through Service Quality Evaluated under SERVQUAL Model- A study on Banking Industries of Bangladesh. Science Journal of Business and Management, 1(4), 88. https://doi.org/10.11648/j.sjbm.20130104.15

[13] Jayasundara, C. C. (2011). A Modular approach to Customer Satisfaction in Relation to Service Quality. Journal of the University Librarians Association of Sri Lanka, 15(1), 23. https://doi.org/10.4038/jula.v15i1.3188

[14] Keshavarz Ghorabaee, M., Amiri, M., Zavadskas, E. K., Turskis, Z., \& Antucheviciene, J. (2017). A new hybrid simulation-based assignment approach for evaluating airlines with multiple service quality criteria. Journal of Air Transport Management, 63, 45-60. https://doi.org/10.1016/j.jairtraman.2017.05.008

[15] Lin, W. (2015). Drawing lines in the sky: The emotional labours of airspace production. Environment and Planning A, 48(6), 1030-1046. https://doi.org/10.1177/0308518X15609219

[16] Parasuraman, A., Zeithaml, V. A., \& Berry, L. L. (1994). Reassessment of Expectations as a Comparison Standard in Measuring Service Quality: Implications for Further Research. Journal of Marketing, 58(1), 111. https://doi.org/10.2307/1252255

[17] Sheffield University 1998. (1998).

[18] Shirouyehzad, H., Hosseinzadeh Lotfi, F., Shahin, A., Aryanezhad, M. B., \& Dabestani, R. (2012). A DEA approach for comparative analysis of service quality dimensions with a case study in hotel industry. International Journal of Services and Operations Management, 12(3), 289-308. https://doi.org/10.1504/IJSOM.2012.047622

[19] Shojaei, P., Seyed Haeri, S. A., \& Mohammadi, S. (2018). Airports evaluation and ranking model using Taguchi loss function, best-worst method and VIKOR technique. Journal of Air Transport Management, 68, 4-13. https://doi.org/10.1016/j.jairtraman.2017.05.006

[20] Sosianika, A., \& Najib, M. F. (2018). Retail service quality scale in the context of Indonesian traditional market. International Journal of Business and Globalisation, 21(1), 19. https://doi.org/10.1504/ijbg.2018.10015254

[21] Suhartanto, D., \& Noor, A. A. (2012). Customer Satisfaction in the Airline Industry: The Role of Service Quality and Price. Asia Tourism Forum Conference, 1-9. http://www.academia.edu/3215480/Customer_Satisfaction_in_the_Airline_Industry_The_Rol e_of_Service_Quality_and_Price

[22] Torres, A. (NUIG). (2014). Marketing Intelligence \& Planning Article information: Marketing Intelligence \& Planning, 32(4), 413-435. 
Exploring the Factors Impacting the Service Quality of the Airline Industry in KSA-Expatriates Viewpoints

[23] Wafik, G., Abou-Shouk, M., \& Hewedi, M. (2017). Airline Passenger Travel Cycle, Satisfaction and Loyalty: A Comparison of EgyptAir and Emirates Airlines. International Journal of Hospitality and Tourism Systems, 10(1), 1-12.

[24] Zia, A. (2020). Exploring Consumers Intent to Download Mobile Application on Android vs . iOS Platforms in Saudi Arabia. Pacific Business Review International, 12(12), 154-182.

[25] Zia, A., \& Hashmi, A. R. (2019). Exploring the factors affecting service quality of zain mobile subscribers in Albaha, Saudi Arabia. International Journal of Innovative Technology and Exploring Engineering, 8(11), 2400-2405. https://doi.org/10.35940/ijitee.J9934.0981119 